This item was submitted to Loughborough's Research Repository by the author.

Items in Figshare are protected by copyright, with all rights reserved, unless otherwise indicated.

\title{
Unusual metal-coordinated zwitterionic P-C-N-C-N-C phosphido adducts
}

PLEASE CITE THE PUBLISHED VERSION

http://dx.doi.org/10.1021/ic1002308

\section{PUBLISHER}

(c) American Chemical Society

\section{VERSION}

NA (Not Applicable or Unknown)

\section{PUBLISHER STATEMENT}

This work is made available according to the conditions of the Creative Commons Attribution-NonCommercialNoDerivatives 4.0 International (CC BY-NC-ND 4.0) licence. Full details of this licence are available at: https://creativecommons.org/licenses/by-nc-nd/4.0/

\section{LICENCE}

CC BY-NC-ND 4.0

\section{REPOSITORY RECORD}

Ekubo, Allen T., Mark R.J. Elsegood, Andrew J. Lake, and Martin B. Smith. 2019. "Unusual Metal-coordinated Zwitterionic P-C-N-C-N-C Phosphido Adducts". figshare. https://hdl.handle.net/2134/15946. 


\title{
Unusual Metal-Coordinated Zwitterionic $\mathbf{P}-\mathrm{C}-\mathrm{N}-\mathrm{C}-\mathrm{N}-\mathrm{C}$ Phosphido Adducts
}

\author{
Allen T. Ekubo, Mark R. J. Elsegood, Andrew J. Lake and Martin B. Smith* \\ Department of Chemistry, Loughborough University, Loughborough, Leics, LE11 3TU, U.K.
}

RECEIVED DATE (will be automatically inserted after manuscript is accepted)

Rare examples of homodinuclear zwitterionic $\mathrm{Pd}^{\prime \prime}$ and $\mathrm{Pt}^{\prime \prime}$ complexes with bridging, two-coordinate $\mathrm{P}\{$ cyclo$\left.\mathrm{CH}_{2} \mathrm{~N}(\mathrm{R}) \mathrm{CHN}(\mathrm{R}) \mathrm{CH}_{2}\right\}$ ligands $\left(\mathrm{R}=4-\mathrm{FC}_{6} \mathrm{H}_{4} \mathrm{CH}_{2}\right.$, $\mathrm{C}_{6} \mathrm{H}_{5} \mathrm{CH}_{2}$ ) have been characterized by single crystal $\mathrm{X}$-ray diffraction using synchrotron radiation. Short $\mathrm{N}-\mathrm{C}$ distances and enlarged $\mathrm{N}-\mathrm{C}-\mathrm{N}$ bond angles support electron delocalization in the central $\mathrm{N}-\mathrm{C}-\mathrm{N}$ backbone.

Two-coordinate phosphorus ligands attract considerable interest for their diverse transition metal chemistry. Phosphenium cations $\left(\mathrm{R}_{2} \mathrm{P}^{+}\right)^{1}$ or phosphido anions $\left(\mathrm{R}_{2} \mathrm{P}^{-}\right)^{2}$ are important classes of two-coordinate phosphorus ligands. Phosphenium ions have been widely studied and stabilized by various donor substituents e.g. aryl/alkylamino ${ }^{3}$, hydrocarbon $^{4}$ and $\mathrm{N}, \mathrm{C}$-bonded $\beta$-diketiminato groups. ${ }^{5}$ Burford and co-workers ${ }^{6}$ have elegantly shown phosphenium cations can be isolated upon coordination to tertiary phosphine ligands. Furthermore, phosphenium ions can readily be stabilized at transition metal centers. ${ }^{1}$ Phosphido ligands are known to bind in a terminal fashion ${ }^{2}$ or, more commonly, bridge two metal centers. ${ }^{2}$ Whilst this bridging mode is common for phosphides, it is considerably more unusual for tertiary phosphines to function in this manner. $^{7}$

As part of continuing studies in our group investigating supramolecular interactions in (di)tertiary phosphines, ${ }^{8}$ we recently reported easily accessible intramolecular $\mathrm{H}$-bonded phosphine analogues of the cage ligand PTA (PTA $=1,3,5-$ triaza-7-phosphaadamantane). ${ }^{8 \mathrm{a}}$ The recent surge in interest with PTA, and its analogues, can be traced to the ease of chemical modification ${ }^{9}$ and diverse coordination, cytotoxic and catalytic properties. ${ }^{10}$ Herein we report the structural characterization of two peculiar homodinuclear zwitterionic $\mathrm{Pd}^{\mathrm{II}}$ and $\mathrm{Pt}^{\mathrm{II}}$ complexes of a partially delocalized sixmembered $\mathrm{P}\left\{\right.$ cyclo- $\left.\mathrm{CH}_{2} \mathrm{~N}(\mathrm{R}) \mathrm{CHN}(\mathrm{R}) \mathrm{CH}_{2}\right\} \quad(\mathrm{R}=4-$ $\mathrm{FC}_{6} \mathrm{H}_{4} \mathrm{CH}_{2}, \mathrm{C}_{6} \mathrm{H}_{5} \mathrm{CH}_{2}$ ) bridging phosphido ligand.

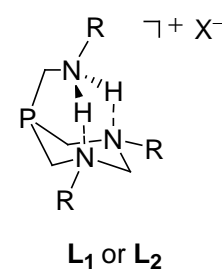

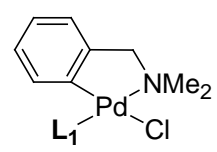

1

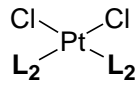

2
Reaction of $\left[\mathrm{Pd}\left(\kappa^{2}-\mathrm{C}_{6} \mathrm{H}_{4} \mathrm{CH}_{2} \mathrm{NMe}_{2}\right)(\mu-\mathrm{Cl})\right]_{2}$ with two equiv. of $\mathbf{L}_{1}\left(\mathrm{R}=4-\mathrm{FC}_{6} \mathrm{H}_{4} \mathrm{CH}_{2} ; \mathrm{X}=\mathrm{Cl}\right)^{8 \mathrm{a}}$ in $\mathrm{CH}_{2} \mathrm{Cl}_{2}$ afforded the cyclometallated complex $\mathbf{1}$ in high yield (78\%). Displacement of the labile acetonitrile ligands from $\left[\mathrm{PtCl}_{2}(\mathrm{MeCN})_{2}\right]$ upon treatment with two equiv. of $\mathbf{L}_{2}(\mathrm{R}=$ $\left.\mathrm{C}_{6} \mathrm{H}_{5} \mathrm{CH}_{2} ; \mathrm{X}=\mathrm{SbF}_{6}\right)^{8 \mathrm{a}}$ in $\mathrm{CH}_{2} \mathrm{Cl}_{2}$ afforded $\mathrm{PtCl}_{2}\left(\mathbf{L}_{2}\right)_{2} 2$ in $82 \%$ isolated yield (see Supporting Information for characterizing data for $\mathbf{1}$ and $\mathbf{2}$ ).

The molecular structure of $\mathbf{1}$ has been confirmed by Xray crystallography (Figure 1) and shows an approximate square-planar geometry about $\mathrm{Pd}(1)$ with $\mathrm{P}(1)$ trans to $\mathrm{N}(4)$ of the cyclometallated ligand. ${ }^{11}$ Around the coordination sphere of $\mathrm{Pd}(1)$, the $\mathrm{Pd}(1)-\mathrm{Cl}(1), \operatorname{Pd}(1)-\mathrm{P}(1), \operatorname{Pd}(1)-\mathrm{C}(26)$ and $\operatorname{Pd}(1)-\mathrm{N}(4)$ distances are as anticipated. ${ }^{11}$ One noticeable feature, and pertinent to structural discussions of 3 and $\mathbf{4}$ (vide infra), are the key metric parameters within the saturated $\mathrm{P}(1)-\mathrm{C}(9)-\mathrm{N}(2)-\mathrm{C}(11)-\mathrm{N}(3)-\mathrm{C}(10)$ ring. The $\mathrm{P}(1)-\mathrm{C}(9) / \mathrm{P}(1)-\mathrm{C}(10)$ [1.826(2) and 1.836(2) $\AA$ ] and $\mathrm{C}(9)-\mathrm{N}(2) / \mathrm{C}(10)-\mathrm{N}(3)$ bond lengths [1.470(3) and 1.458(3) $\AA$ ] are all in accord with formal single bonds. 
Furthermore, the $\mathrm{N}(2)-\mathrm{C}(11) / \mathrm{C}(11)-\mathrm{N}(3)$ distances [1.468(3) $\AA, 1.457(3) \AA$ ] are consistent with single bonds and the $\mathrm{N}(2)-\mathrm{C}(11)-\mathrm{N}(3)$ bond angle is $110.19(18)^{\circ}$. The $\Sigma\left[\mathrm{N}(2) / \mathrm{N}(3)\right.$ angles] are $330.5^{\circ}$ and $332.6^{\circ}$ respectively, clearly indicating a distorted pyramidal geometry about each $\mathrm{N}$ atom. Finally, intramolecular $\mathrm{N}-\mathrm{H} \cdots \mathrm{N}$ hydrogen bonding [N(1) $\cdots \mathrm{N}(3)$ 2.895(3) $\AA, \mathrm{H}(1 \mathrm{~A}) \cdots \mathrm{N}(3)$ 2.43(3) $\AA$, $\mathrm{N}(1)-\mathrm{H}(1 \mathrm{~A}) \cdots \mathrm{N}(3) \quad 111.8(19)^{\circ} ; \mathrm{N}(1) \cdots \mathrm{N}(2) \quad 2.944(3) \AA$, $\left.\mathrm{H}(1 \mathrm{~B}) \cdots \mathrm{N}(2) \quad 2.31(3) \quad \AA, \quad \mathrm{N}(1)-\mathrm{H}(1 \mathrm{~B}) \cdots \mathrm{N}(2) \quad 137(2)^{\circ}\right]$ conformationally locks the ligand structure through interactions between $-\mathrm{NH}_{2}{ }^{+}$and both ternary nitrogen centers. The structural parameters for $\mathbf{1}$ are similar to those of the non coordinated ligand $\mathbf{L}_{1}{ }^{8 a}$

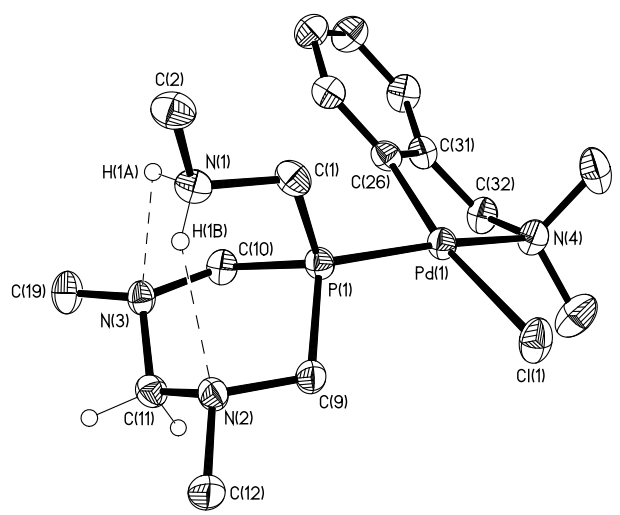

Figure 1. ORTEP of part of the cation in $\mathbf{1}$ showing the H-bonded ring conformation. Thermal ellipsoids are drawn at the $50 \%$ probability level. All $\mathrm{C}-\mathrm{H}$ hydrogen atoms except those on $\mathrm{N}(1)$ and $\mathrm{C}(11)$ are omitted for clarity. Selected bond distances $(\AA)$ and angles (deg): $\operatorname{Pd}(1)-\mathrm{P}(1)$ 2.2247(6), $\mathrm{Pd}(1)-\mathrm{Cl}(1)$ 2.3955(6), $\mathrm{Pd}(1)-\mathrm{N}(4)$ 2.156(2), $\mathrm{Pd}(1)-\mathrm{C}(26)$ 1.997(2), $\mathrm{P}(1)-\mathrm{C}(1)$ 1.836(2), C(1)-N(1) 1.494(3); C(9)-P(1)-C(10) 100.70(11), $\mathrm{P}(1)-\mathrm{C}(9)-\mathrm{N}(2)$ 110.38(15), $\mathrm{C}(9)-\mathrm{N}(2)-\mathrm{C}(11)$ 110.79(18), $\mathrm{C}(11)-\mathrm{N}(3)-\mathrm{C}(10)$ 111.54(18), N(3)-C(10)-P(1) 110.83(15).

The X-ray crystal structures of $\mathbf{3}$ (Figure 2) and $\mathbf{4}$ (Supporting Information) have been determined and are unique. $^{12}$ In $\mathbf{3}$ and $\mathbf{4}$, there is a central homodinuclear " $\mathrm{M}_{2} \mathrm{Cl}_{4} \mathrm{P}_{2}$ " arrangement $(\mathrm{M}=\mathrm{Pd}, \mathrm{Pt})$ with the bridging $\mu^{2}$ phosphido ligand perpendicular to this plane. Compound 3 lies on an inversion center about the midpoint defined by the $\mathrm{Pd}_{2} \mathrm{P}_{2}$ core. Along the $\mathrm{P} \cdots \mathrm{P}$ vector, the two 16-electron " $\mathrm{MCl}_{2}$ " metal fragments are slightly distorted, from planarity, by $13.0^{\circ}$ (for 3 ) and $2.1^{\circ}$ (for both independent molecules in 4). The $\mathrm{M}-\mathrm{P}$ distances are essentially equivalent [2.2418(12), 2.2350(12) $\AA$ for 3; 2.2316(11), 2.2250(10) and 2.2235(10), 2.2314(11) $\AA$ for 4] suggesting a near symmetric bonding motif of the $\mu^{2}$-bridging phosphide in both cases. Moreover the Pd-P bond lengths in $\mathbf{3}$ are slightly longer than those found in $\mathbf{1}$.

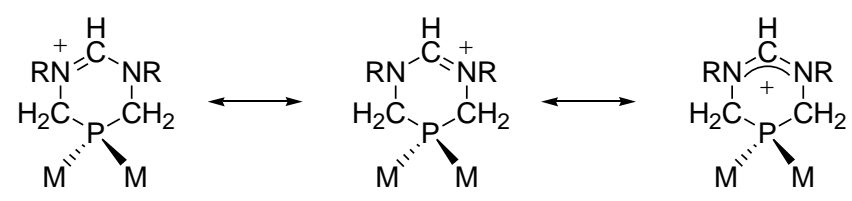

The coordinated ligand, in $\mathbf{3}$ and $\mathbf{4}$, can be regarded as zwitterionic whereby the positive charge is located on the central $\mathrm{N}-\mathrm{C}-\mathrm{N}$ backbone and the negative charge (not shown) on the $\mathrm{P}$ atom (or more likely the Pd metal center thereby satisfying a 16 -electron count). ${ }^{13}$ Consequently the central $\mathrm{N}-\mathrm{C}-\mathrm{N}$ carbon atom has undergone a change in hybridization from $\mathrm{sp}^{3}$ (in 1) to $\mathrm{sp}^{2}$ (in $\mathbf{3}$ and $\mathbf{4}$ ). Support for electron delocalization of the positive charge into the $\mathrm{N}-\mathrm{C}-\mathrm{N}$ backbone comes from the contracted $\mathrm{N}-\mathrm{C}$ bond lengths $[\mathrm{N}(1)-\mathrm{C}(2) 1.311(6) \AA$ and $\mathrm{C}(2)-\mathrm{N}(2)$ 1.320(6) $\AA$ for 3; $\mathrm{N}(1)-\mathrm{C}(2)$ 1.302(5) [1.306(5)] $\AA$ and $\mathrm{C}(2)-\mathrm{N}(2)$ 1.303(5) [1.312(5)] $\AA$ for 4] and expanded $\mathrm{N}-\mathrm{C}-\mathrm{N}$ angles $\left[127.1(4)^{\circ}\right.$ for 3 ; $126.1(4), 127.6(4)$ for 4$] .^{14}$ The $\sum\left[\mathrm{N}(2) / \mathrm{N}(3)\right.$ angles] for both structures are ca. $360^{\circ}$ respectively clearly indicating the $\mathrm{N}$ atoms adopt a planar configuration. Within each six-membered ring, the $\mathrm{C}-\mathrm{N}-\mathrm{C}-\mathrm{N}-\mathrm{C}$ atoms are essentially co-planar $( \pm 0.043 \AA$ for 3; $\pm 0.061,0.054,0.043,0.031 \AA$ for 4). Furthermore, in 3 the $\mathrm{P}(1)$ atom lies out of this plane by $0.866 \AA$ [hinge angle between mean planes $\mathrm{C}(1) / \mathrm{N}(1) / \mathrm{C}(2) / \mathrm{N}(2) / \mathrm{C}(3)$ vs. $\mathrm{C}(1) / \mathrm{P}(1) / \mathrm{C}(3)=45.4^{\circ}$ ] while in 4 , the equivalent hinge angles lie in the range $44.2-46.6^{\circ}$. The metric parameters for 3 and 4 clearly support a two-coordinate P-ligand. ${ }^{2}$ Finally, in 3 the $\operatorname{Pd}(1) \cdots \operatorname{Pd}(2)$ separation is $3.556 \AA$ sugges-

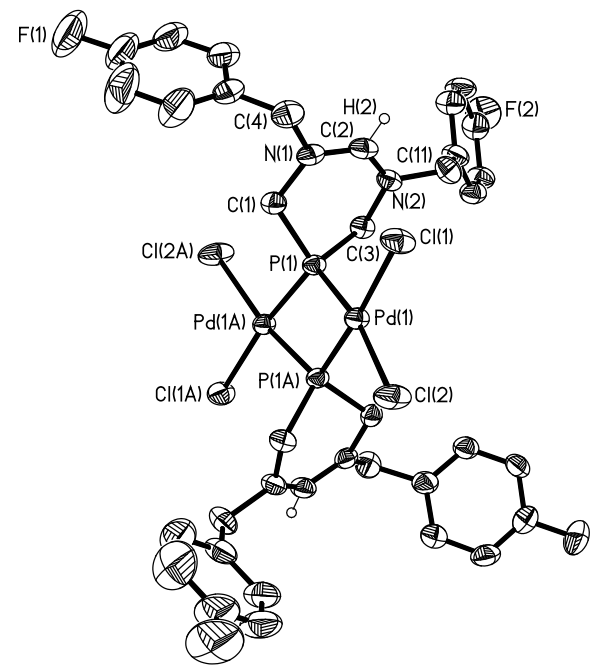

(a)

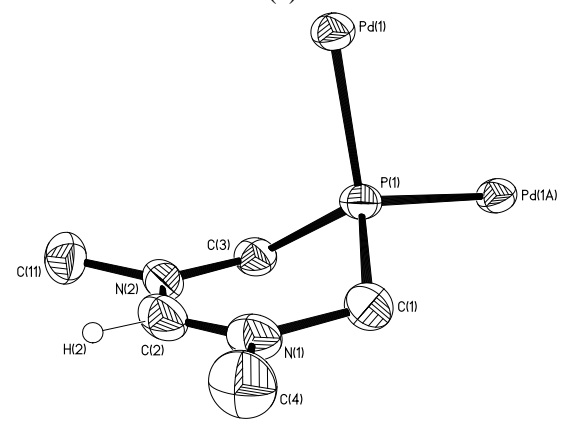

(b)

Figure 2. (a) ORTEP of 3. Thermal ellipsoids are drawn at the 50\% probability level. The disordered dmso solvent molecule, minor phenyl disorder component on $\mathrm{N}(2)$ and all $\mathrm{C}-\mathrm{H}$ hydrogen atoms except on $\mathrm{C}(2)$ are omitted for clarity. (b) ORTEP view showing the envelope ring conformation. Selected bond distances $(\AA)$ and angles (deg): $\mathrm{Pd}(1)-\mathrm{Cl}(1)$ 2.3736(12), $\mathrm{Pd}(1)-\mathrm{Cl}(2)$ 2.3842(13), $\mathrm{P}(1)-\mathrm{C}(1)$ 1.825(5), $\mathrm{C}(1)-\mathrm{N}(1)$ 1.469(6), $\mathrm{N}(2)-\mathrm{C}(3)$ 1.475(6), $\mathrm{C}(3)-\mathrm{P}(1)$ 1.835(4); $\mathrm{Cl}(1)-\mathrm{Pd}(1)-\mathrm{P}(1)$ 98.62(4), $\mathrm{Cl}(1)-\mathrm{Pd}(1)-\mathrm{P}(1 \mathrm{~A})$ 172.34(4), $\mathrm{Cl}(1)-\mathrm{Pd}(1)-\mathrm{Cl}(2)$ 94.00(5), $\mathrm{P}(1)-\mathrm{Pd}(1)-\mathrm{P}(1 \mathrm{~A}) \quad$ 73.84(5), $\quad \mathrm{P}(1 \mathrm{~A})-\mathrm{Pd}(1)-\mathrm{Cl}(2) \quad 93.60(4)$, 
$\mathrm{P}(1)-\mathrm{Pd}(1)-\mathrm{Cl}(2)$ 167.12(5), $\mathrm{P}(1)-\mathrm{C}(1)-\mathrm{N}(1)$ 112.6(3), $\mathrm{C}(1)-\mathrm{N}(1)-\mathrm{C}(2)$ 124.4(4), C(2)-N(2)-C(3) 123.2(4), N(2)-C(3)-P(1) 110.3(3).

ting the absence of any single metal-metal bonding and similarly seen for $4[\operatorname{Pt}(1) \cdots \operatorname{Pt}(2) / \operatorname{Pt}(3) \cdots \operatorname{Pt}(4) 3.520 / 3.521$ A].

Although the mechanism for formation of $\mathbf{3}$ and $\mathbf{4}$ is unclear at present, one plausable pathway involves carbocation $^{15}$ formation via hydrogen abstraction $/ \mathrm{H}_{2}$ elimination from the central $-(\mathrm{R}) \mathrm{N}-\mathrm{CH}_{2}-\mathrm{N}(\mathrm{R})-$ backbone. Elimination of “(R) $\mathrm{NHCH}_{2}-$ ", possibly as [(R)NH=CH$]^{+}$, affords a highly reactive mononuclear terminal phosphido complex. Displacement of a tertiary phosphine $\mathbf{L}_{2}$ (for 2 ) or adventious $\mathrm{HCl}$ protonation ${ }^{16}$ of the cyclometallated $\mathrm{C}, \mathrm{N}$ ligand (for 1), followed by dimerization, may account for the formation of the observed homodinuclear complexes.

In summary, homodinuclear late-transition metal centers can be used to stabilize unexpected zwitterionic, twocoordinate phosphorus ligands in a bridging ligation mode. Further studies are currently underway to investigate preparative routes to these highly unusual phosphido ligands and probe the mechanism for their transformation.

Acknowledgment. We would like to thank the EPSRC, Loughborough University, and Niger Delta University, Bayelsa State, Nigeria, for funding (A.T.E., A.J.L.). Rhodia UK Ltd. (Dr. Ranbir Padda) and Johnson Matthey are gratefully acknowledged for their kind donations of THPC and metal salts, respectively. Dr Kevin Flower is thanked for helpful discussions.

Supporting Information Available: Synthetic details, characterizing data and X-ray data for $\mathbf{1}, \mathbf{3}$ and $\mathbf{4}$ in CIF format and additional figures and details. This material is available free of charge via the Internet at http://pubs.acs.org.

* To whom correspondence should be addressed. E-mail: m.b.smith@lboro.ac.uk.

(1) (a) Cowley, A. H.; Kemp, R. A. Chem. Rev. 1985, 85, 367-382. (b) Gudat, D. Coord. Chem. Rev. 1997, 163, 71-106.

(2) (a) Mastrorilli, P. Eur. J. Inorg. Chem. 2008, 4835-4850. (b) Jain, V. K.; Jain, L. Coord. Chem. Rev. 2005, 249, 3075-3197.

(3) (a) Dube, J. W.; Farrar, G. J.; Norton, E. L.; Szekely, K. L. S.; Cooper, B. F. T.; Macdonald, C. L. B. Organometallics 2009, 28 , 4377-4384. (b) Burck, S.; Gudat, D. Inorg. Chem. 2008, 47, 315-321. (c) Abrams, M. B.; Scott, B. L.; Baker, R. T. Organometallics 2000, 19, 4944-4956.

(4) Reed, R. W.; Xie, Z.; Reed, C. A. Organometallics 1995, 14, 5002-5004.

(5) Lu, Z.; Reeske, G.; Moore, J. A.; Cowley, A. H. Chem. Commun. 2006, 5060-5061.

(6) (a) Burford, N.; Herbert, D. E.; Ragogna, P. J.; McDonald, R.; Ferguson, M. J. J. Am. Chem. Soc. 2004, 126, 17067-17073. (b) Burford N.; Ragogna, P. J. J. Chem. Soc., Dalton Trans. 2002, 4307-4315.

(7) (a) Leca, F.; Lescop, C.; Rodriguez-Sanz, E.; Costuas, K.; Halet, J.F.; Réau, R. Angew. Chem. Int. Ed. 2005, 44, 4362-4365. (b) Sauthier, M.; Le Guennic, B.; Deborde, V.; Toupet, L.; Halet, J.-F.; Réau, R. Angew. Chem. Int. Ed. 2001, 40, 228-231. (c) Pechmann, T.; Brandt, C. D.; Werner, H. Angew. Chem. Int. Ed. 2000, 39, 3909-3911.

(8) (a) Ekubo, A. T.; Elsegood, M. R. J.; Lake, A. J.; Smith, M. B. Inorg. Chem. 2009, 48, 2633-2638. (b) Smith, M. B.; Dale, S. H.; Coles, S. J.; Gelbrich, T.; Hursthouse, M. B.; Light, M. E.; Horton, P. N. CrystEngComm 2007, 9, 165-175.

(9) Erlandsson, M.; Gonsalvi, L.; Lenco, A.; Peruzzini, M. Inorg. Chem. 2008, 47, 8-10.

(10) For recent examples, see: (a) Bolaño, S.; Rodríguez-Rocha, M. M.; Bravo, J.; Castro, J.; Oñate, E.; Peruzzini, M. Organometallics 2009, 28, 6020-6030. (b) Nair, R. P; Kim, T. H.; Frost, B. J.
Organometallics 2009, 28, 4681-4688. (c) Servin, P.; Laurent, R. Gonsalvi, L.; Tristany, M.; Peruzzini, M.; Majoral, J.-P.; Caminade, A.-M. Dalton Trans. 2009, 4432-4434. (d) Renfrew, A. K.; Phillips, A. D.; Egger, A. E.; Hartinger, C. G.; Bosquain, S. S.; Nazarov, A. A.; Keppler, B. K.; Gonsalvi, L.; Peruzzini, M.; Dyson, P. J. Organometallics 2009, 28, 1165-1172.

(11) Ruiz, J.; Cutillas, N.; López, F.; López, G.; Bautista, D. Organometallics 2006, 25, 5768-5773.

(12) (a) CSD version 5.30 plus three updates. Allen, F. H. Acta Crystallogr., Sect. B 2002, 58, 380-388. A CSD search revealed the following complexes of the tertiary phosphine $\mathrm{PhP}\{$ cyclo$\left.\mathrm{CH}_{2} \mathrm{~N}(\mathrm{Ph}) \mathrm{CH}_{2} \mathrm{~N}(\mathrm{Ph}) \mathrm{CH}_{2}\right\}$ have been structurally determined: TECZAC, YUXKAD, YUXKEH and YUXNEK. (b) The United Kingdom Chemical Database Service, Fletcher, D. A.; McMeeking, R. F.; Parkin, D. J. Chem. Inf. Comput. Sci. 1996, 36, 746-749.

(13) (a) Boubekeur, L.; Ricard, L.; Le Floch, P.; Mézailles, N. Organometallics 2005, 24, 3856-3863. (b) Gudat, D.; Häp, S.; Nieger, M. J. Organomet. Chem. 2002, 643-644, 181-188.

(14) Coles, M. P.; Hitchcock, P. B. Chem. Commun. 2007, 5229-5231.

(15) Zagumennov, V. A.; Karasik, A. A.; Nikitin, E. V.; Nikonov, G. N. Russ. Chem. Bull. 1997, 46, 1154-1157.

(16) Murahashi, S.-I.; Tamba, Y.; Yamamura, M.; Yoshimura, N. J. Org. Chem. 1978, 43, 4099-4106. 
Single crystal X-ray crystallography has been used to elucidate the solid state structures of an unusual pair of homodinuclear zwitterionic complexes $\mathrm{M}_{2} \mathrm{Cl}_{4}\left[\mu^{2}-\mathrm{P}\right.$ \{cyclo- $\left.\left.\mathrm{CH}_{2} \mathrm{~N}(\mathrm{R}) \mathrm{CHN}(\mathrm{R}) \mathrm{CH}_{2}\right\}\right]_{2}(\mathrm{M}=\mathrm{Pd}, \mathrm{R}=4$ $\mathrm{FC}_{6} \mathrm{H}_{4} \mathrm{CH}_{2}$ (shown below); $\mathrm{M}=\mathrm{Pt}, \mathrm{R}=\mathrm{C}_{6} \mathrm{H}_{5} \mathrm{CH}_{2}$ ).
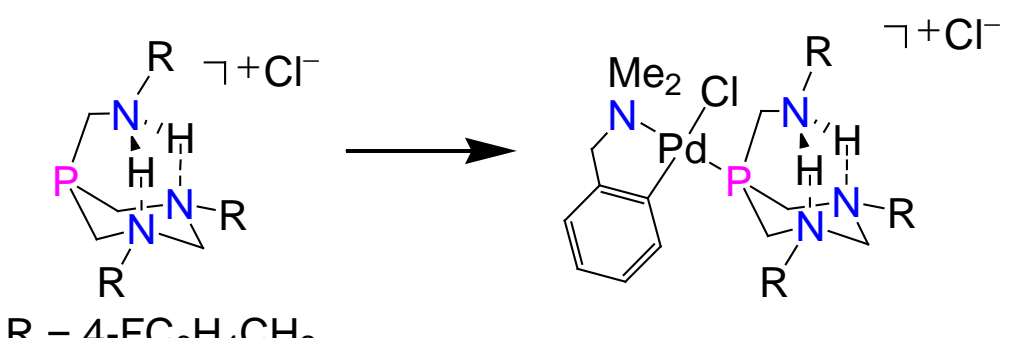

1 (major)

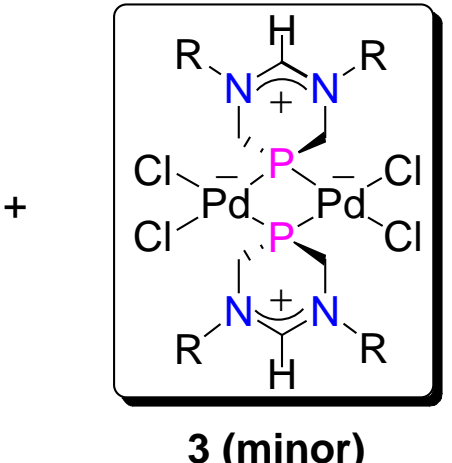

